\title{
Justice for Migrant Women Workers: An Exploration from Electronics Manufacturing Sector
}

\author{
Dr. Megha Shree \\ Research Fellow, People Research on India's Consumer Economy (PRICE) \\ meghashreejmi@gmail.com
}

Acknowledgement: Author is heartily thankful to Professor Shakti kak (Former faculty, Centre for Jawaharlal Nehru Studies, Jamia Millia Islamia and Dr. Balwant Singh Mehta (Fellow, Institute for Human Development) for their constant guidance and timeless help. The author dedicates this paper to both of her mentors.

Abstract: Over the years, women's participation in industrial and service sector has increased in developing countries as well as in India as a result of shift from traditional agriculture sector. In particular, electronics manufacturing has shown a huge potential to create new employment opportunities. In view of this, the main objective of the present study is to explore the working conditions of women workers especially migrants in electronics manufacturing industry. The study has adopted 'Decent Work' framework of International Labour Organisation to examine the objectives. This study is based on household level secondary data of National Sample Survey (Government of India) and field survey conducted among 100 migrant women workers in electronics firms situated in the National Capital Regions (Noida).This research is based on an inter-disciplinary perspective to examine the women workers' rights at the workplace in the electronics industry. There is a dearth of studies related to migrant women employed in this modern sector. The study provides important insights, which can help in improving the employment conditions of women workers in the overall manufacturing industries and contribute to the future policy making.

Keywords: Migrant Women, Women and labour, Women workers, Electronics Manufacturing Sector, Decent Work.

\section{INTRODUCTION}

Women in developing countries like India have been largely engaged in the agriculture sector and their participation has increased in the non-agriculture sector which has gone nearly doubled from 19 per cent to 37 per cent during 1983 to 2011-12.. The structural change theory of economic growth claimed that the shift of economic activities from agriculture to industry and services is necessary for the growth of modern economies (Kaldor, 1967). The globalisation process and technological advances have motivated the large corporations moved to developing countries to maintain their profits and to retain the competitive edge over their rivals who have also led to changes in the nature and pattern of employment and labour practices. In this process, they preferred female workers, who are ready to work at flexible conditions ${ }^{1}$ (Standing, 1999; Bacchus, 2005). This trend is particularly common in labour-intensive industries such as electronics and garments manufacturing, where the production of high-value consumer goods are obtained from all over the world through a network of global suppliers often based in developing countries (Kaur, 2004). Arthur Lewis dual sector theory of tradition

1 Flexible conditions refer to low wages, long working hours, at contractual/casual position and at lower occupational levels.

www.arjonline.org 
Justice for Migrant Women Workers: An Exploration from Electronics Manufacturing Sector

and modern sector describe that with increasing population and the entry of women into the labour force in developing countries, surplus labour in traditional or agriculture sector has shifted to the modern sector or industry. This provides wages above the subsistence level. As a result of the development in the modern sector employment, output and the share of profits in national income also increases. Ultimately, in the long run surplus labour can be fully absorbed into the modern sector (Lewis, 1954). Thus, the economy shifts from a dual to a single incorporated labour market and real wages increase with growing productivity in agreement with traditional growth models. This process becomes self-sustaining and led to modernization and economic development. It is referred as Lewisian turning point and discussed widely in recent years in the context of economic development in China and India (Bloomberg, 2010).

Over the years, women's share in India's manufacturing sector in urban areas has also gone up by 2 percentage points (27 per cent to 29 per cent) from 1983 to 2011-2. While the share of male workers decreased by 4 percentage points ( 27 per cent to 23 per cent) during the same period. This shift of women from agriculture to industry can be explained partly by the rise in employment opportunities in urban areas. In India, the share of migrant women workers (55.5 per cent) in manufacturing sector dominates with respect to non-migrant women in the same sector ( 44.5 per cent). Therefore, it may be argued that industries prefer migrant workers over local workers. There is a shift from traditional to modern sector is creating decent jobs in the labour market (ILO, 2011). However, it is argued that this linear explanation has not always been proved true in empirical studies.

These migrant workers are mainly found in domestic work or assembly jobs in manufacturing sector (Mazumdar, 2007). It is documented that globally women's participation in modern manufacturing such as electronics industry is much higher than that of men (SAHRDC, 2012). A large part of women workers in electronics industry in India consists of migrants, who moved to urban or semi-urban locations from rural areas for better employment opportunities (Chhachhi, 1999). In this process of shifting, on one hand where are getting benefitted in terms of accessing employment while on the other hand, high concentration of migrant women workers in modern urban manufacturing industries such as electronics is often more exploited at their workplace (Rustagi, 2012; UN Women, 2011).

Electronics is an emerging sector and National Policy on Electronics (NPE) has also estimated that the sector will provide direct jobs to 28 million people by 2020. These jobs will be more than five times of the present employment in the sector, i.e. 4.5 million (ESC, n.d: 22). This indicates that electronics manufacturing sector has immense potential to create new employment opportunities for the huge youth population of the country and can also contribute to economic growth. There are few available studies that show a contrasting view on women's work in the industry. One set of studies argued that women workers in this sector are mostly employed as contractual, casual, part-time and informal with poor working condition (Mazumdar, 2007). Another set of studies highlights that women's share in regular or formal jobs as well as their real earnings has improved over the years (ILER, 2014)2 ${ }^{2}$ Studies have been undertaken at macro and micro level \{Mazumdar (2007); Elson and Pearson (1981); Banerjee (1988); Hensman, (1988); Banerjee (1997); Chhachhi (1997); Malcolm (2004) ; Kaur (2004) ; Metcalfe (2004); Sen (2004); Mehta (2012); Gangoli (2007); Alam (2009); Lal (2011); Bacchus (2005); Lerche (2012); Chaudhari and Panigrahi (2013); Shree (2015)\} but there is lack of analytical documentation on these issues. Hence, there is an urgent need for a systematic study on the present issue. Therefore, access to justice for migrant women workers in electronics industry is an important topic to study and also relevant in the present context, when electronics manufacturing sector has emerged as a preferential sector for the development of the industry.

2 The share of the manufacturing sector in employment has been increased to 13 per cent in 2011-2 compared to 11 per cent in $2009-10$. Another significant trend in the labour market is the increasing share of regular wage and salaried workers, who now constitute 17.9 per cent of the total employment up from 14 per cent in 1999-00.

American Research Journal of Humanities and Social Sciences

Page 2 
Justice for Migrant Women Workers: An Exploration from Electronics Manufacturing Sector

The main objective of the paper is to examine the working conditions of migrant women workers in electronics manufacturing sector in India. The present paper adopts the ILO's concept of "Decent Work" which aims to secure decent work for everyone and decent work approach (ILO, 1999a) which involves "opportunities for work that is productive and delivers a fair income, security at the workplace and social protection for families, organize and participate in the decisions that affect their lives and equality of opportunity and treatment for all women and men" (Naughton and Diane, 2011). The present paper is based on both primary and secondary data sources. Secondary data sources include published materials like books, journals, documents, Internet, and Government of India reports (National Sample Survey Organisation reports, Annual Survey of Industries reports and Labour Bureau Reports \{Ministry of Labour and Employment\}). Primary sources include the data collected in a sample field survey of migrant women workers to know their perspective. The two levels that have been adopted for the analysis are given in Figure: 1. The analysis is based on the rounds of National Sample Survey information on employment and unemployment in India for the years 1993-4, 2004-5 and 2011-2. In addition, employment, unemployment and migration data (64 ${ }^{\text {th }}$ round; Schedule 10.2$)$ for the latest available years (2007-8) has been used to get to know the migrants in the industry with special reference to electronics manufacturing sector. The electronics manufacturing sector has been identified according to the OECD (2007) classification and by using the National Industrial Classification Codes (NIC, 2008) at the four-digit level. In order to match up the particulars of electronics manufacturing sector, the NIC concordance has been done at five-digit level, which helped in getting the similar codes for over the years. Only working age (15-59 years) of the population has been used for the analysis. The analysis has been done based upon the Usual Principal Status (UPS) of the NSS that refers to the main work during last 365 days only. In total 100 migrant women workers were interviewed ${ }^{3}$ across small, medium and large firms using the purposive and snowball (reference) sampling method. The next section conceptualise the justice framework in labour market.

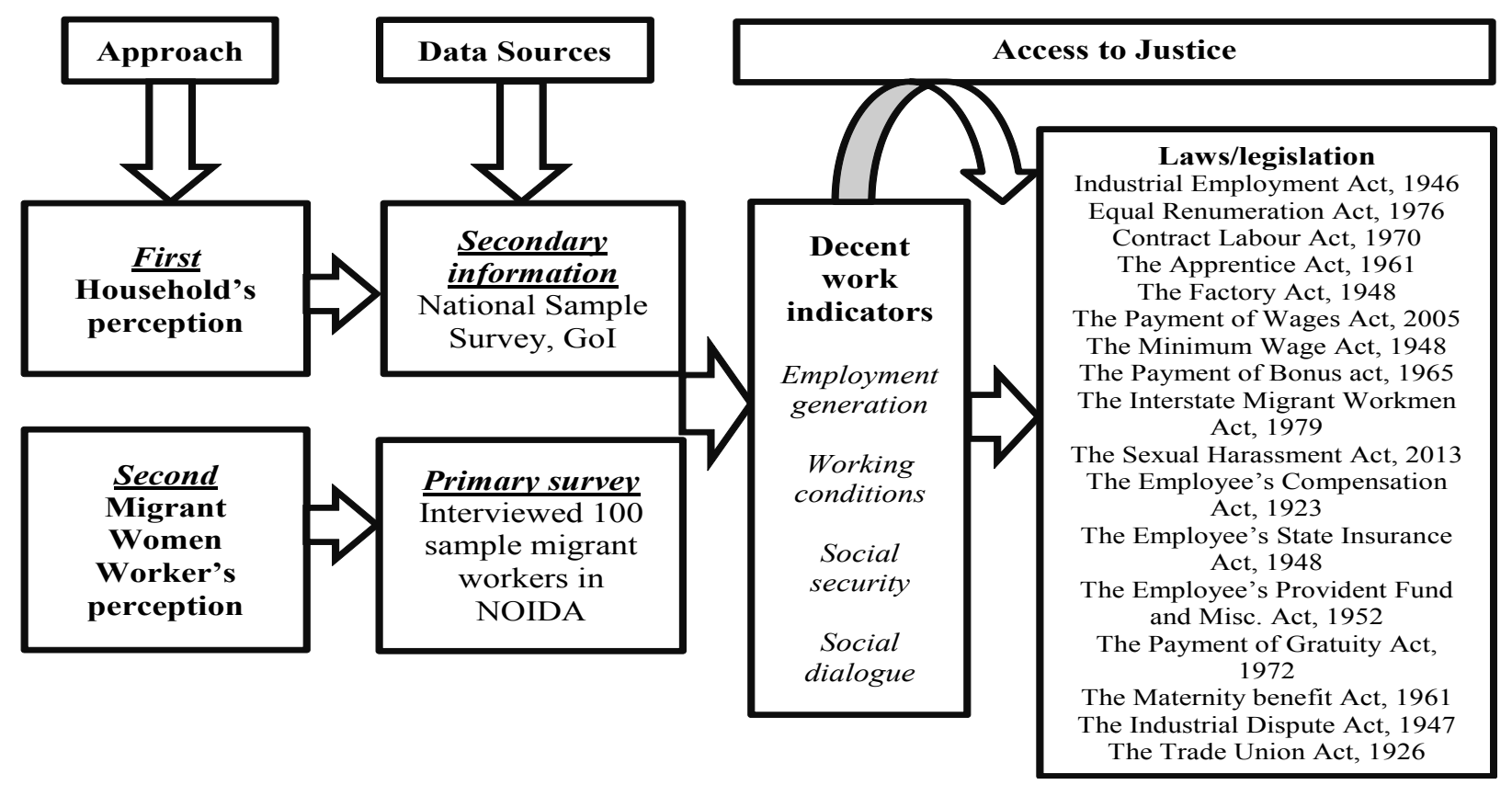

Fig1. Study Framework

3 The researcher stood outside the firms in order to interview the respondents, and sometimes interviewed them at their houses, if they agreed. An in-depth discussion with some selected respondents was also conducted to understand the context in detail.

American Research Journal of Humanities and Social Sciences

Page 3 
Justice for Migrant Women Workers: An Exploration from Electronics Manufacturing Sector

\section{JUSTICE In LABOUR MARKET: CONCEPTUAl FRAMEWORK}

Access to Justice' is a dynamic concept that has evolved over the years and varies in different disciplines. Each discipline has its own approach to look at justice. It is beyond the scope of this work to analyse all the dimensions of justice. Therefore, the present study aims to delineate the justice theories in the context of women and work.

The concept of justice was first discussed by Greek philosophers Plato and Aristotle. They explained the idea of justice based on the idealistic approach (Sahoo, 1988) which stresses on unequal distribution of resources based on individual's social position in the society. Plato explained that justice can be accessed when each person received goods that they deserved based on their prescribed position in the social order. On the other hand, Aristotle explains justice as equality and applied only to individuals who occupy the equal position ("formal equality") in the principle that ensures social order by regulating the distribution of benefits (Sahoo, 1988). However, their approach did not discuss the women's position. Their writings emphasized that biological differences were the decisive factor in that society which describes "Men as breadwinner and women as caregivers" (Busby, 2006).

Further, Locke, Rousseau and Hobbes are the main proponents of social contract theory, who basically meant to give an explanation of a hypothetical origin of civil society and state (Sahoo, 1988). Before civil society was formed, men were living in the state of nature without law and authority to maintain peace in that state of nature and were guided solely by their instinct of self-preservation. Thus, monarch was supposed to be the ultimate authority and had power of making and interpreting laws which were essential for a just society (Sahoo, 1988). In addition, Locke and Rousseau emphasized on the significance of natural laws and natural rights which focused on the individual liberties and equality of opportunity, rights, outcomes and values of human well-being (Acharya, 2008). Marx rejected their ideas and explained that the root of injustice lies in the political and economic structure based on discrimination, exploitation and privilege (Sahoo, 1988). He argued that justice would prevail when individuals received what they need on the basis of their humanity and not on what they deserved because of social order and authority of state. Their ideas on the status of women were always that the relationship between men and women are meant for procreation. On the concept of individual liberty, they were being criticized that "If all men are born free, why are women born slaves?" (Busby, 2006).

In the backdrop of idealistic and contractualistic approach, Rawls set out the theory of distributive Justice. Rawls' notion of distributive justice is "All social values are to be distributed equally unless an unequal distribution of any or all of these values is to everyone's advantage (Menon, 2008)". The fundamental principles of the theory of distributive justice were: (i) Each person has equal right to the most extensive system of personal liberty compatible with a system of total liberty for all (ii) Social and economic inequality are to be managed so that they are available with the greatest benefit to the least advantaged in society (Menon, 2008). Carole Pateman and Susan Okin opposed Rawls on his ideas of equality and opportunities. Pateman argued that the women are meant to remain in private spheres as a household entity and Okin stresses on the patriarchal structure of the family where Rawl's failed to highlight the same (Huang, n.d.).

Sen extended Rawl's approach of equality of opportunity and explained it in the form of capabilities. He argued that equality of opportunity cannot be guaranteed by equal distribution as described in the Rawl's distributive justice. But capabilities represent freedom to access primary goods at their own will (Menon, 2008). It focuses on maintaining individual capacities/capabilities through social arrangements to get optimal well-being (Sen, 2008). Martha Nussbaum followed Sen's concept and explained the capabilities approach focusing on women 
empowerment perspective. She argued that although Sen highlights that the equality is a fundamental goal for women who pursue social justice but he never said "to what range equality of capability ought to be a social goal or how it ought to be shared with other political values in the pursuit of social justice" (Nussbaum, n.d.). She emphasized that capabilities are related to human rights. According to her, human rights are guaranteed by virtue of being human and an individual have a reasonable assertion to have the capability available to the one; thus right appears prior to the capability and provides a sound ground for securing of a capability (Nussbaum, 1997). She extended that rights possesses value that stresses on people's choice and autonomy, which motivates them to avail opportunities and not simply by their actual functioning but by providing them the sense of self-independence and belongingness (Nussbaum, 1997).

Internationally, there are various provisions formulated regarding human rights. The documents highlighting individual rights such the Magna Carta (1215), the English Bill of Rights (1689), the French Declaration on the Rights of Man and Citizen (1789) and the US Constitution and Bill of Rights (1791) are pioneering and contemporary human rights documents. These were biased in nature and excluded women, minorities, people of colour, and members of certain social, religious, economic, and political groups (IBO, 2012). On December 10, 1948, the Universal Declaration of Human Rights (UDHR) was adopted which is based on the principles of universality and non-discrimination (SAHRDC, 2012) which are commonly known as the International Bill of Human Rights (Flowers, n.d.). The International Covenant on Civil and Political Rights (ICCPR) focuses civil and political rights, while the International Covenant on Economic, Social and Cultural Rights (ICESCR) focuses on economic and cultural rights". Gender equality has been the prime agenda of United Nations. "Article 3 of the ICESCR requires states parties to undertake and to ensure the equal rights of men and women for the enjoyment of all economic, social and cultural rights set forth in the Covenant (UNHR, n.d.)". This ensures women's capabilities in labour market and encourages them to enter into labour market without any obstacle. The Convention on the Elimination of All Forms of Discrimination against Women (CEDAW) is a crucial human rights law which acknowledges women's rights in the best possible way. The Convention provides the basis for creating equality between women and men for safeguarding women's equal access to political and public life especially in the employment.

Further, ILO deals with the convention of decent work whose mandate involves "opportunities for work; security at the workplace; social protection for families; better prospects for social integration; freedom to express their concerns; equality of opportunity and treatment for all (ILO, n.d.)". The ILO further defined that decent work is an essential component for livelihood. The overall goal of decent work is to provide the respectable working conditions to the people with fair opportunity. In addition, The ILO introduced 'Migration for Employment Convention in 1949'; 'Migrant Workers Convention in 1975' and 'Convention on Decent Work for Workers in 2011' for the rights of migrant workers. Apart from international conventions and provisions, the Indian constitution gives civil and political rights to women, which are contained in Part III (Fundamental rights) of the Constitution which are justifiable and enforced in the court of law. While economic, social and cultural rights are contained in Part IV (Directive Principle of State Policy) and are non-enforceable in court of law but are fundamental to governance (SAHRDC, 2012)5. ]

4 Civil and political rights are referred to First generation rights and provide guarantee for an individual in relationship to state, while economic and cultural rights are termed as Second generational rights which necessitate certain actions and provisions by the state in order for it to fulfill its obligations. First generation rights are mentioned in Article 3 to 21 while Second generation rights are mentioned in Articles 22 to 27 in UDHR. It is an undeniable fact that civil and political rights can never be enjoyed in the absence of basic social, economic and cultural rights (SAHRDC, 2012).

5 Articles 14, 19(1)(c), 21, 23 and 24 form part of the Fundamental Rights guaranteed under Part III of the Constitution. Articles 38, 39 , 39-A, 41, 42, 43, 43-A and 47 form part of the Directive Principles of State Policy under Part IV of the Constitution (Neelakantapillai, 2010). 
Justice for Migrant Women Workers: An Exploration from Electronics Manufacturing Sector

The Indian government has also formulated several industrial laws related to workers' rights. These acts regulate the working hours and also contain provisions of health, safety and welfare of women workers. They guarantee equality before law and equal treatment to women workers. As discussed earlier, majority of these laws have been motivated by the conventions and recommendations adopted by the ILO. The main objectives of these laws are to empower the women to increase their efficiency, their participation in useful services, to ensure their welfare, and to provide equal pay for equal work. The above mentioned conceptual part consolidates the active access to justice as elementary condition which senses the right to work for all. Basically, it should be reachable to all and consequently that are individually and socially just (Bridgman, 2007). Further section analyses that how this concept of justice is applicable for migrant women workers in India's electronics manufacturing sector.

\section{MIGRANT WORKFORCE IN INDIAN INDUSTRY}

Overall, the share of female migrants in the agriculture was around three-fourth of the total workers. But share of women in manufacturing sector (8.3 per cent) stands at third, which was slightly less than public administration, health and education ( 9.2 per cent), etc. In urban areas, the share of female migrants engaged in manufacturing sector was relatively higher with 22.8 per cent, which ranks second than public administration, health, and education (37.2 per cent). On the other hand, majority of the male migrants were engaged in manufacturing sector at both all-India levels as well as in urban area. This confirms the existence of significant share of migrants in the manufacturing sector in India (Table: 1)

Table1. Distribution of Migrant Workforce by Industrial classification (UPS): 2007-8.

\begin{tabular}{|c|c|c|c|c|c|c|c|c|c|}
\hline \multirow[b]{2}{*}{ Industry } & \multicolumn{3}{|c|}{ Rural } & \multicolumn{2}{|l|}{ Urban } & \multicolumn{3}{|c|}{ Total } & \multirow[b]{2}{*}{$\mathbf{P}$} \\
\hline & $\mathbf{M}$ & $\mathbf{F}$ & $\mathbf{P}$ & $\mathbf{M}$ & $\mathbf{F}$ & $\mathbf{P}$ & $\mathbf{M}$ & $\mathbf{F}$ & \\
\hline Agriculture, etc. & 36.0 & 83.5 & 75.0 & 2.7 & 14.3 & 5.6 & 13.6 & 74.5 & 52.1 \\
\hline Mining \& Quarrying & 1.3 & 0.4 & 0.6 & 0.8 & 0.3 & 0.7 & 1.0 & 0.4 & 0.6 \\
\hline Manufacturing & 17.2 & 6.1 & 8.1 & 27.1 & 22.8 & 26.1 & 23.9 & 8.3 & 14.0 \\
\hline Electricity, Gas \& Water supply & 0.8 & 0.0 & 0.1 & 1.1 & 0.3 & 0.9 & 1.0 & 0.0 & 0.4 \\
\hline Construction & 10.1 & 2.4 & 3.8 & 9.3 & 6.0 & 8.4 & 9.5 & 2.9 & 5.3 \\
\hline Trade, Hotel \& restaurants & 13.4 & 2.3 & 4.3 & 21.4 & 12.8 & 19.2 & 18.8 & 3.7 & 9.2 \\
\hline Transport, Storage \& Comm. & 6.4 & 0.1 & 1.3 & 12.0 & 1.8 & 9.5 & 10.2 & 0.3 & 4.0 \\
\hline Finance, Business, Real Est, etc & 2.0 & 0.1 & 0.5 & 7.9 & 4.5 & 7.0 & 5.9 & 0.7 & 2.6 \\
\hline Public Adm Health, edu., etc & 12.8 & 5.0 & 6.4 & 17.7 & 37.2 & 22.6 & 16.1 & 9.2 & 11.7 \\
\hline Total & 100 & 100 & 100 & 100 & 100 & 100 & 100 & 100 & 100 \\
\hline
\end{tabular}

Source: Various rounds of Unit level data of Employment and Unemployment Surveys, NSSO, Government of India.

Note: M-Male; F-Female; P-Person 
Justice for Migrant Women Workers: An Exploration from Electronics Manufacturing Sector

One of the objectives of the study is to analyse the situation of the female migrant workers in the electronics manufacturing sector in India. Female migrant workers dominate in the manufacturing sector. The main reason emerges out of it as migration to urban areas is evolving as a livelihood option. Although stereotypical constructions of women's place still exist but it is also a matter of fact that women are progressively looking at their place in the labour market too (Banerjee and Raju, 2009). At all India level more than (55.5 per cent) half of the female workers in the manufacturing sector were migrants and around 41 per cent in the electronics manufacturing sector. Overall, one-third (33 per cent) of the workers in manufacturing and in a similar proportion (35.3 per cent) in electronics manufacturing were migrants, which were relatively less among male compared to female (Figure: 2 and 3).

Fig2. Percentage Distribution of Migrant Workforce in Manufacturing (UPS): 2007-8.

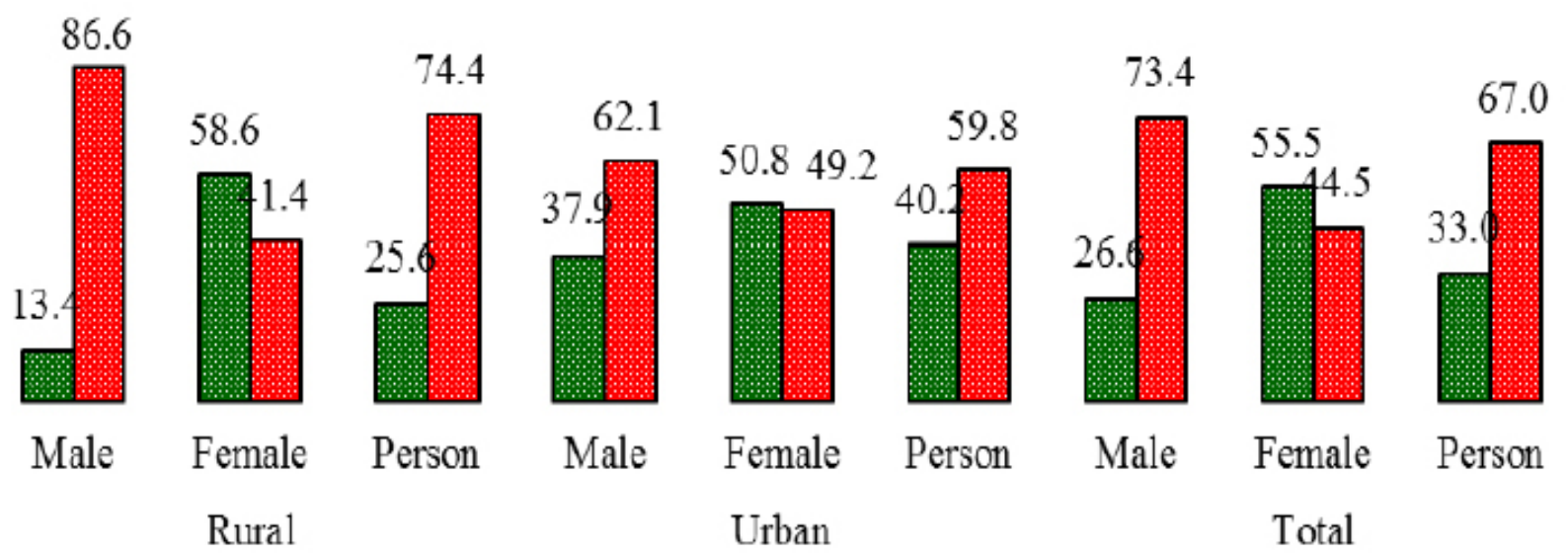

Source: National Sample Survey, 2007-8, Unit level data, NSSO, Government of India

Fig3. Percentage distribution of migrant workforce in Electronics Manufacturing (UPS): 2007-8.

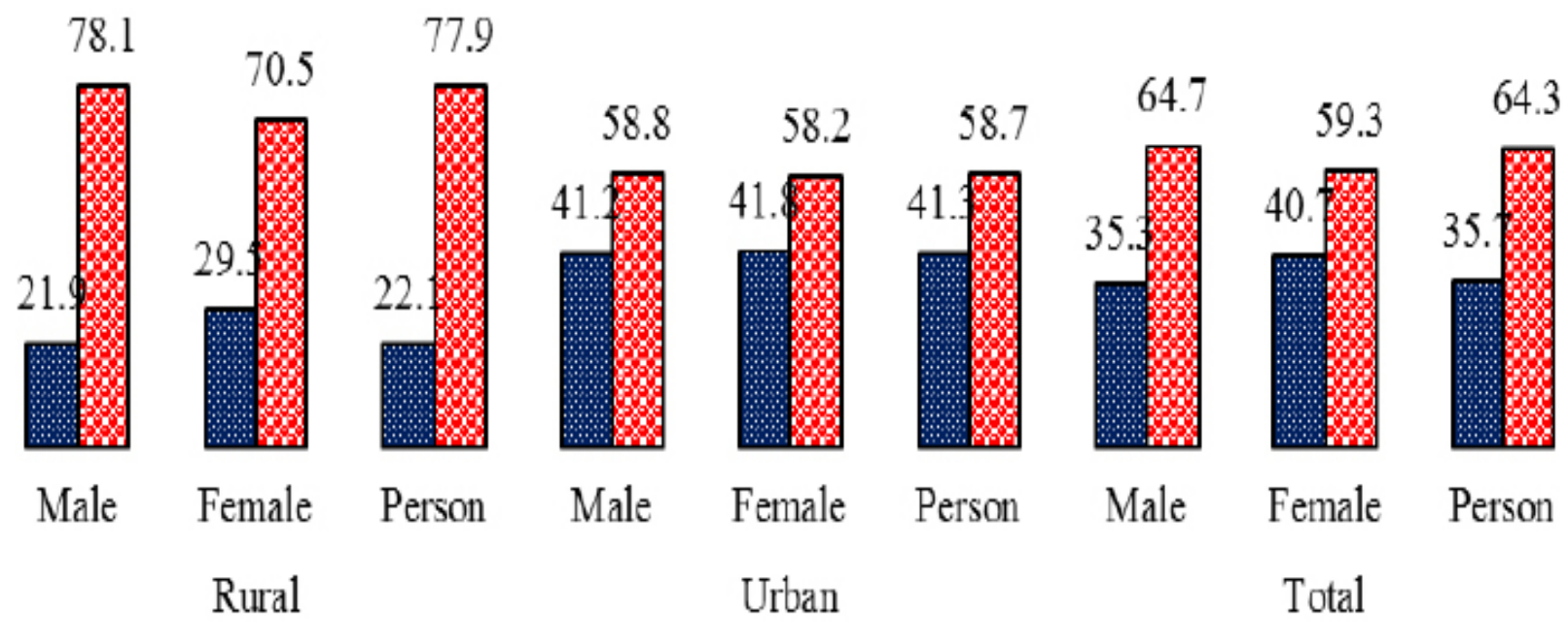

\section{Migrant 0 Non-migrant}

Source: National Sample Survey, 2007-8, Unit level data, NSSO, Government of India 
Mazumdar, Neetha and Agnihotri (2013) pointed out that the share of regular employment among urban migrant women workers showed striking increase. Majority of the male (87.3 per cent) and female (86.1 per cent) workers in electronics manufacturing sector were also employed as regular workers followed by self-employed (10 per cent) and casual workers (2.8 per cent). The share of male migrants working as regular workers in manufacturing was relatively higher both in rural and urban area.

Fig4. Percentage Distribution of Migrant Workforce in Electronics Manufacturing Sector by Employment Status (UPS): 2007-8.
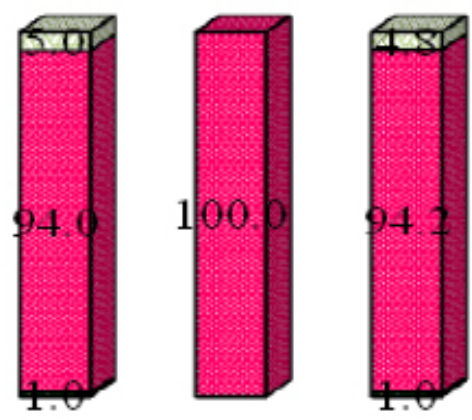

Male Female Person
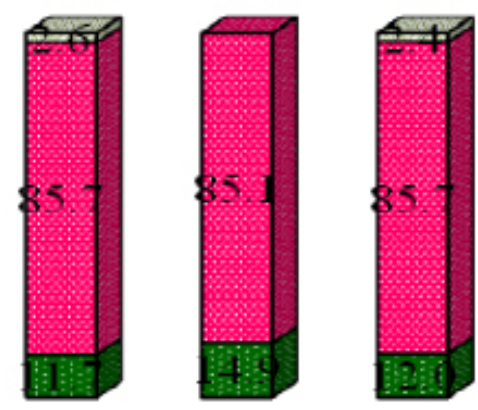

Male Female Person
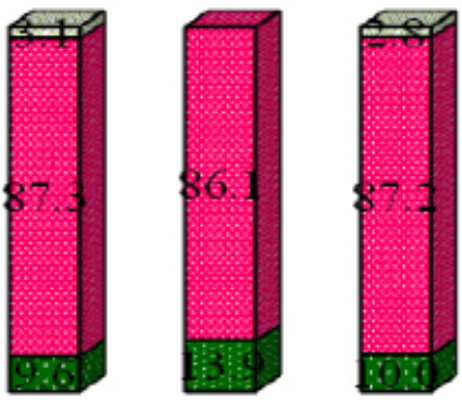

Male Female Person

Rural

Urban

\section{⿴囗十 Self Employed $\quad$ Regular a Casual}

\section{Total}

\section{Source: National Sample Survey, 2007-8, Unit level data, NSSO, Government of India}

The rise in the regular salaried employment is not an indication of having decent work. The discussion has been around the rise of the regular salaried employment but the question arises that what type of regularity is it? Here the regularity is termed as without maternity leave, medical leave, provident fund, health insurance, day-care/crèche facilities and work at low paid wage (Mazumdar, Neetha and Agnihotri, 2013).

Globally studies also highlight the vulnerable working conditions of migrant women workers in electronics manufacturing sector. Bormann et al. (2010) reveals that the salaries paid to the migrant workers were less than the basic 'living wage' and they were delayed or not paid at all. (SOMO,2013). Workers also face pressures of deportation on being absent due to any reason, even on grounds of illness. Furthermore, being dependent legally on employers and outsourcing agents, migrant workers remain vulnerable to exploitation and have no access to justice. In export-oriented industries such as the garment industry and the electronics industry in Cambodia, Malaysia and Thailand, the issue of negligence in implementing labour welfare legislations appeared prominently (War on Want, n.d.). Working environments are unfavourable to migrant women workers welfare mainly due to lack of access to health care and other basic services. Migrant women workers are deprived of their reproductive rights. The limitation of these studies is that there are hardly any data sets exist (globally as well as in Indian context) which highlights about the working conditions of migrant women workers in India particularly in electronics manufacturing sector. In order to know the exact situation of the ground (which is missing till now particularly with reference to this sector), the present article attempts to analyse the conditions of migrant women workers in electronics manufacturing sector through the primary survey conducted in NOIDA which is considered as a hub for electronics manufacturing sector. Before reaching to it, following section attempts to present the conditions of workers in overall electronics manufacturing sector in India. 


\section{Workers In Indian Electronics MANufacturing SECtor}

The electronics manufacturing sector constitutes small portion (1.2 per cent) of manufacturing sector and considered as an importance sector due to its emerging and future expansion prospects. Out of total workforce engaged in the electronics manufacturing sector, around 12 per cent constitute female and 88 per cent male respectively (NSS 2011-2). Majority of female work force belongs to the age-group of 30-44 (40.3 per cent) and 15-29 years (37 per cent) and least in 45-59 years (22.7 per cent). It is argued that in electronics manufacturing sector (Chhachhi, 1999; Mazumdar, 2007) the employers prefer young, unmarried or single or deserted female workforce who can devote themselves fully to work without possessing any other familial responsibilities. More than half of female workers in electronics manufacturing sector were either unmarried (34 per cent) or widows/deserted (22 per cent). This reveals the prevailing preference for young and single women in electronics industry. There were significant differences between male and female workers' education levels where around one-third ( 30 per cent) of the female workers compared to just only 2 per cent male were illiterate reflects the presence of skill polarisation. This difference in the type of skill could be the reason for relatively higher representation of female workers in low-skilled occupations or lower level of employment in the industry. The main objective to the paper is to analyse the access to justice in terms of decent work which has been classified by International Labour Organisation (ILO) are as follows: Employment Generation, Employment Conditions, Social Security and Social Dialogue (Ghai, 2003).

In terms of Employment Generation, this was mainly dominated by the limited companies (49.8 per cent) in which more than half of the women workers (56.4 per cent) were engaged. 87.1 per cent of the workforce in electronics manufacturing sector were regular salaried followed by self-employed mainly own account workers (7.3 per cent) and unpaid family workers ( 2.7 per cent). Out of which, nearly three-fourth (73 per cent) of female in the sector were regular salaried, which was comparatively lower than their male (89.1 per cent) counterparts. On the other hand, the share of female (12.3 per cent) in unpaid family work and casual work was relatively higher than male (1.1 per cent) in the sector. Although, the share of femalex in regular work is fairly high but the question arises does it guarantees about their decent working conditions. This can be explained through a crucial analysis i.e. the horizontal occupational analysis which reveals that women were dominated in lower level jobs like office clerks, assemblers, cleaners, related trade and precision workers. Their presence in middle and lower jobs like secretaries and key board- operating clerks, and other machine operators and assemblers was relatively higher. However there is some presence of women at top and middle level jobs which is comparatively less than their male counterparts. (Table: 2). This is strong evidence to the aspect of gender-based inequality in this sector. Therefore, it confirms about the pre-defined segregation of roles at the workplace and integration of women into lower level or paid jobs in the factory settings (Hensman, 1988).

Table2. Job Hierarchy based on Top 10 Occupational levels National Classification of Occupation (2004) in Electronics Manufacturing Sector (UPS): 2011-2 (in \%)

\begin{tabular}{|l|l|l|l|l|}
\hline Occupation & Vertical & \multicolumn{2}{l|}{ Horizontal } \\
\hline Directors and Chief Executives & Male & Female & Male & Female \\
\hline General managers & 2.7 & 0.1 & 99.5 & 0.5 \\
\hline Production \& operations department managers & 2.3 & 0.0 & 100.0 & 0.0 \\
\hline Architects, engineers and related professionals & 7.2 & 0.0 & 100.0 & 0.0 \\
\hline
\end{tabular}


Justice for Migrant Women Workers: An Exploration from Electronics Manufacturing Sector

\begin{tabular}{|l|l|l|l|l|}
\hline Occupation & Vertical & \multicolumn{2}{l|}{ Horizontal } \\
\hline Top Level & Male & Female & Male & Female \\
\hline Physical \& Engineering Science technicians & 14.0 & 3.0 & 97.4 & 2.6 \\
\hline Electrical \& electronic equipment mechanics \& fitters & 3.5 & 8.2 & 77.5 & 22.5 \\
\hline Administrative associate professionals & 9.4 & 0.9 & 98.9 & 1.1 \\
\hline Computing professionals & 0.6 & 0.4 & 92.2 & 7.8 \\
\hline Business professionals & 2.6 & 0.0 & 100.0 & 0.0 \\
\hline Middle Level & 4.7 & 0.0 & 100.0 & 0.0 \\
\hline Other Office Clerks & 20.8 & 9.5 & 94.7 & 5.3 \\
\hline Material recording \& transport clerks & 0.7 & 13.0 & 29.4 & 70.6 \\
\hline Numerical clerks & 3.4 & 0.0 & 100.0 & 0.0 \\
\hline Secretaries \& key board- operating clerks & 0.9 & 1.2 & 86.7 & 13.3 \\
\hline Lower Middle Level & 1.3 & 1.2 & 89.9 & 10.1 \\
\hline Blacksmith, Tool Makers \& Related Trades workers & 6.3 & 15.4 & 76.9 & 23.1 \\
\hline Assemblers & 0.1 & 11.0 & 8.1 & 91.9 \\
\hline Precision Workers in Metal and Related Materials & 0.3 & 9.7 & 21.7 & 78.3 \\
\hline Metal moulders, welders, sheet metal workers, structural & 2.7 & 4.8 & 82.1 & 17.9 \\
\hline metal preparers \& related trades workers & & & & \\
\hline Painters, building cleaners \& related trade workers & 0.1 & 1.1 & 47.2 & 52.8 \\
\hline Other machine operators \& assemblers & 1.8 & 0.7 & 95.2 & 4.8 \\
\hline Manufacturing labourers & 1.8 & 11.7 & 55.1 & 44.9 \\
\hline Optical \& electronic equipment operators & 5.7 & 0.0 & 100.0 & 0.0 \\
\hline Personal care workers & 4.6 & 0.0 & 100.0 & 0.0 \\
\hline Lower Level & 17.9 & 44.3 & 76.6 & 23.4 \\
\hline Sol. & & 5.3 & 49.2 & 50.8 \\
\hline
\end{tabular}

Source: Unit level data of Employment and Unemployment Surveys (2011-2), NSSO, Government of India

In terms of Employment conditions, male workers proportion was higher than female for a contract of more than 3 years. There is a feel of relief that the access to paid leave was relatively more among female workers ( 63.3 per cent) compared to their male (56 per cent) counterparts. But it does not shows that they are better off. Falkus said that wages strongly determines the discrimination at concrete level. Table: 3 presents the at all India level the average daily earnings of regular workers was 2.8 times higher than casual workers, which is 3.1 times in case of electronics manufacturing sector. The gap in average daily earnings of male and female for both regular and casual workers was also higher in electronics (1.9 and 2.2) compared to overall (1.4 and 1.5). It can be inferred that most of the female are engaged in regular employment but get average earnings almost half their male counterpart. Further, the female (88 per cent) workers received regular monthly payment relatively less than male (98.4 per cent) and the former only paid on the piece rate basis (12 per cent). This piece rate wages for female indicate the outsourcing practice of big firms to small enterprises called own account enterprise 
(OAE) and non-directory established having less than 6 workers. This suggests a greater degree of contractual and flexibility amongst the female workforce compared to the male, which also reflects from the earlier analysis of status of workers and job contract period.

Table3. Average Daily Earnings of Workers (UPS): 2011-2

\begin{tabular}{|c|c|c|c|c|}
\hline Status & Male & Female & Person & Male/Female \\
\hline \multicolumn{5}{|c|}{ Overall } \\
\hline Regular & 413 & 303 & 392 & 1.4 \\
\hline Casual & 155 & 105 & 142 & 1.5 \\
\hline Regular/Casual & 2.7 & 2.9 & 2.8 & - \\
\hline \multicolumn{5}{|c|}{ Electronics manufacturing } \\
\hline Regular & 544 & 291 & 519 & 1.9 \\
\hline Casual & 187 & 86 & 168 & 2.2 \\
\hline Regular/Casual & 2.9 & 3.4 & 3.1 & - \\
\hline \multicolumn{5}{|c|}{ Electronics/ Overall } \\
\hline Regular & 1.3 & 1.0 & 1.3 & - \\
\hline Casual & 1.2 & 0.8 & 1.2 & - \\
\hline
\end{tabular}

Source: Unit level data of Employment and Unemployment Surveys, 2011-12, NSSO, Government of India

In terms of Social security benefits, nearly 45 per cent of the workers were not eligible for any of the social security benefits. Around one-quarter of the females ( 25.8 per cent) avail major social security benefits that was relatively higher than their male counterparts (20.2 per cent). On the other hand, less than half of female (14.5 per cent) were availing some social security compared to the male (31.5 per cent). There was also a huge difference in non-eligibility of social security between male (59.8 per cent) and female (43.1 per cent). In terms of social dialogue, the awareness regarding the presence of unions or associations among males in electronics manufacturing sector was 33.5 per cent, which was almost five times higher among than female (6.8 per cent). However, there was marked difference between male (87 per cent) and female (18.4 per cent) membership with the union. Reported reasons for literature regarding the non-participation of women with the trade unions, were that trade unions are unconcerned about the women's demands. Unions, while offering collective benefits, are extremely lax, if not downright disinterested in the problems of women workers. Many union leaders are themselves sexist and view women in a subordinate role both within the union and at work. (Banerjee,1991). The above analysis provides the base that how women workers face discrimination in this sector also as they generally does everywhere. Such type of micro level studies is the strength for the policy makers as well to get to know the ground reality before taking any concrete decisions. The further section is going to present the heart of the study which is even missing in secondary level literature as well.

\section{Noida's Electronics Manufacturing Sector: Migrants Reflections}

India's electronic hardware industry is mainly situated in three regions --- the Northern Region around Delhi known as National Capital Region (NCR), Western Region around Mumbai,Pune and the Southern Region around Bangalore, Hyderabad and Chennai respectively. Concept of NCR has been developed in order to accommodate migrants. In order to reduce the overburdening, to control the congestion in Delhi and also for balanced regional development, concept of National Capital Region came into existence. Mazumdar (2007) mentioned about the relocation and establishment of large number of electronics manufacturing units from OKHLA, DELHI to NOIDA in the era of 90's. It is also well known fact that NOIDA consists of Electronics Manufacturing giant's viz. SAMSUNG, PANASONIC, MOSER BAER, LG, HCL, and BPL-SANYO and so on. Because of dual reason of presence of migrants and as well as electronics manufacturing units, it has been considered as universe for the study. 
Field visits in NOIDA illustrates that the sample highlights that majority ( 60 per cent) of the workers belonged to medium/large enterprises followed by small and DME respectively. Nearly three-fourth (73 per cent) of respondents belonged to 18-29 years of age group and nearly 63 per cent of the migrant women workers were single (unmarried, divorced and separated) which which confirm the findings about the predominance of young and single women labour (Chhachhi, 1999; Mazumdar, 2007) in the sector. As far as state of enumeration is concerned, majority migrant women workers belonged to Bihar followed by West Bengal, Uttarakhand, and other parts of Uttar Pradesh and so on. Although, the majority of them migrated due to employment related reasons for migration but the common argument highlighted by respondents are "Although female's migration is associated with their families but our ultimate aim is to earn for living and contribute to household income otherwise we could have stayed at the native places as well". This extends the findings as workers in the industry migrate initially for their personal reasons only and later get into employment. Similar issue has also been raised by available studies as statistics presented by Government of India fails to capture the motives of women migration, which may enter the labour force after migrating as a member of a migrating household (IDRC, 2014).

In terms of Employment Opportunity, all of them were engaged in the shop floor activities particularly in mounting of components followed by checking, helping, fitting, cutting, soldering and quality control respectively. Around 40 per cent of the sample respondents were working with present company for the last 12 months or 1 year only which reveals that "In Electronics Industry, majority of the women are on short term employment. Employers give them breaks, when they are about to complete a year term. Another common practice now- a-days is that during the joining they are asked to signed on a blank paper. One of the migrant women workers was asked to leave and re-join within one week time period with some other name." The same practice was also confirmed by one of the Human Resource professional of a leading electronics manufacturing firms that "Short term job employment pattern is now common in the industry to avoid proper annual increments and bonus, we are compelled to provide breaks to the workers. In most of the cases, they re-employ them. This is an important step of cost cutting and consequently remains free from contractor/consulting agencies." Several women workers pointed out towards no specific job profile in the industry. Table 4 presents the distribution of respondents by their work duration in present company and nature of work. Those workers who have been working in the present company for the last 0-6 months primarily engaged in component mounting (31 per cent) followed by checking ( 25 per cent) helping or assisting (15 per cent) and fittings (15 per cent) job. Similarly, workers who have been working for the last 7-12 months primarily involved in mounting (25.9 per cent), fitting (25.9 per cent) and helping (22.2 per cent) job. It may be argued that there is no specific distinction and categorization of women's work in the electronics industry. The workers who possessed more than 5 years of experience in the industry were still involved in mounting, checking and cutting jobs.

Table4. Nature of work of Respondents

\begin{tabular}{|l|l|l|l|l|l|l|}
\hline Nature of Work & \multicolumn{6}{|c|}{ Work duration } \\
\cline { 2 - 7 } & $\mathbf{0 - 6}$ months & $\mathbf{7 - 1 2}$ months & $\mathbf{1 - 3}$ years & $\mathbf{3 - 5}$ years & $\mathbf{5}$ yrs \& above & Total \\
\hline Helper & 15.4 & 22.2 & 16.7 & 5.3 & 0.0 & 15.0 \\
\hline Quality Control & 53.8 & 25.9 & 27.8 & 21.1 & 60.0 & 31.0 \\
\hline Soldering & 0.0 & 0.0 & 0.0 & 10.5 & 0.0 & 2.0 \\
\hline Checking & 0.0 & 3.7 & 2.8 & 0.0 & 0.0 & 2.0 \\
\hline Fitting & 23.1 & 14.8 & 27.8 & 36.8 & 20.0 & 25.0 \\
\hline Cutting & 7.7 & 25.9 & 11.1 & 10.5 & 20.0 & 15.0 \\
\hline Total & 0.0 & 7.4 & 13.9 & 15.8 & 0.0 & 10.0 \\
\hline
\end{tabular}

Source: Field Survey, 2014-5. 
Justice for Migrant Women Workers: An Exploration from Electronics Manufacturing Sector

In terms of working conditions, overwhelming 99 per cent workers worked on an average for 49-60 hours per week, i.e. 9-10 hours per day for six days a week. In addition, the firm size wise analysis shows that workers in DMEs and small enterprises workers worked more than stipulated working hours per day, i.e. more than 8 hours. Nearly 32 per cent of them said about working continuously for more than 5 hours per day without any interval. This phenomenon was more pronounced in DMEs and small enterprises, whereas workers in medium/large enterprises provided enough break time in between. In this regard, Section 59 of the Factories Act 1948 states that "Every adult cannot work for more than 48 hours in a week and not more than 9 hours in a day. According to Section 51 of the Act, the spread over should not exceed 10-1/2 hours", (Pay check, 2015). Further Section 33 of the Minimum Wage Act 1948 states that "For overtime, wages are to be paid at the rate of twice the ordinary rates of wages of the worker. It mentions that the employer can take actual work on any day up to 9 hours in a 12 hours shift. But he must pay double the rates for any hour or part of an hour of actual work in excess of nine hours or for more than 48 hours in any week" (Pay check, 2015). Table: 5 presents the incidence of overtime and related activity. Over 79 per cent of the respondents received ordinary or regular wages and only 21 per cent received double wages for the overtime work.

Table5: Mode of Payment of Respondent

\begin{tabular}{|l|c|c|c|c|}
\hline & DME & Small & Medium/Large & Total \\
\hline Ordinary pay & 71.4 & 78.8 & 80.0 & 79.0 \\
\hline Double pay & 28.6 & 21.2 & 20.0 & 21.0 \\
\hline Total & 100.0 & 100.0 & 100.0 & 100.0 \\
\hline
\end{tabular}

Source: Field Survey, 2014-5.

Other workplace facilities to the responded women workers were appeared to be provided and satisfied with the availability of water facility at employer's cost (96 per cent), provisions of separate toilets ( 98 per cent), and sweeper's availability at employer's cost (98 per cent). Table 6 shows that majority of the respondents reported about availability of first aid facility in their respective firms. However, only 5 per cent of them reported about availability of Crèche facility in their firms. This facility was available only medium/large firms.

Table 6: First Aid and Crèche in the Firms

\begin{tabular}{|l|c|c|c|c|}
\hline Working condition & DME & Small & $\begin{array}{c}\text { Medium/ } \\
\text { Large }\end{array}$ & Total \\
\hline First aid & 85.7 & 90.9 & 86.7 & 88.0 \\
\hline Crèche & 0.0 & 0.0 & 8.3 & 5.0 \\
\hline Paid leave & 0.0 & 6.1 & 46.7 & 30.0 \\
\hline
\end{tabular}

Source: Field Survey, 2014-15.

Ninety one (91) per cent of the responded migrant women workers were totally unsatisfied with the insufficient working space, in particular those working in DMEs and small enterprises. Women workers are put in small rooms without any ventilation. Each room consisted of 14-15 women workers. Few migrant women workers complained of headaches and pain into their eyes. Thus, it raises an important issue of health which is associated with the women workers in electronics industry. Workplace health issues of workers are the crucial concerns in the industrial settings. According to International Labour Organisation (ILO) estimates, "Over one million work-related deaths occur annually and hundreds of millions of workers suffer from workplace accidents and occupational exposure to hazardous substances worldwide" (ILO, 2015). This issue is common amongst female workers. Globally, women workers working in the electronics manufacturing sector suffer from reproductive health problems, respiratory and skin disorders, high blood lead levels, work stress, musculoskeletal disorders and so on (Leilanie, 2011). But, this aspect is least explored in Indian context. In this background, Figure 5 
Justice for Migrant Women Workers: An Exploration from Electronics Manufacturing Sector

presents the health problems among respondents. Majority of them suffered from headache followed by back pain, vertigo, eyes pain and shoulder pain and few also reported about tiredness and dizziness. Musculoskeletal disorders (MSD) were widely reported because assembling work in Indian electronics manufacturing requires continuous sitting or standing which may be responsible for such health problem viz. cervical spondylitis. It can be argued that continuous sittings and bending posture during work led to the skeletal disorders which create the harmful effects on the health of women workers in the industry.

Figure5. Health problems of Respondents

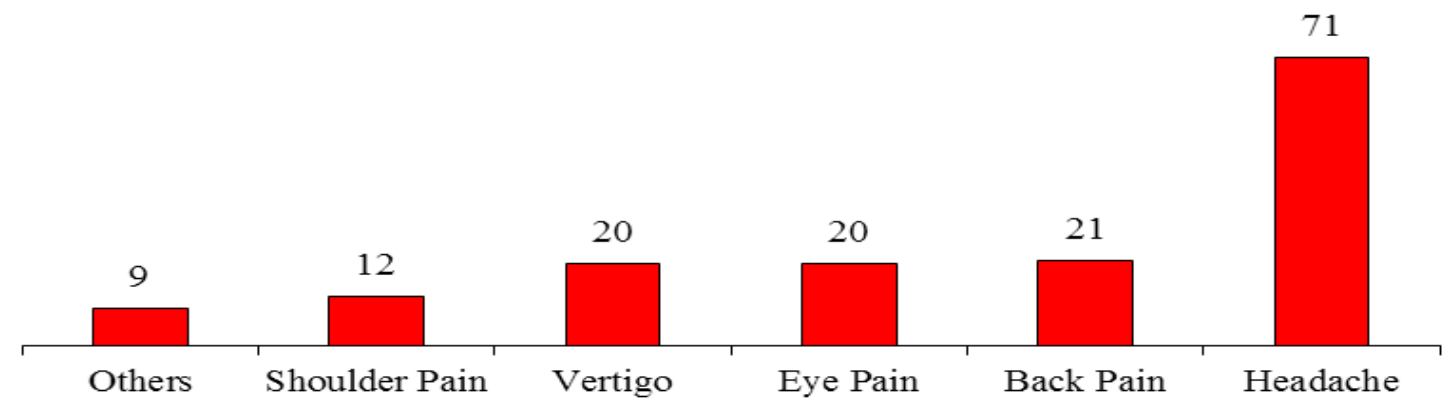

Source: Field Survey, 2014-5.

Note: Percentages do not add hundred because of multiple responses

Only few workers complained about the non-payment of annual increment in their salary. Average monthly salary paid in DMEs (Rs. 6671/-) to permanent workers was higher compared to small enterprises (Rs.6258/-). This may be one of the strategies adopted by DMEs to retain their workers. Average monthly salary of contractual worker (Rs 6700/-) in medium/large enterprises was higher than that of regular workers (Rs 6671/-) in DMEs and small enterprises (Rs 6258/-). It may be argued that "Employers manipulate the salary of workers. They promised them for regular annual salary increment but at that time he always gives us some excuses viz. Firm is running short with funds and lack of business opportunities." The respondents reported that there exist differences in male and female salary in electronics manufacturing industry. This phenomenon was observed particularly in DMEs because of non-existence of any rule and regulations. Few of them explained that males are generally paid more because they perform various other jobs like sales or delivery, whereas female are mostly placed at fixed tasks of helping to checking only. As far as payment of salary on time is concerned, 82 per cent of the respondents were satisfied with the receipt of salary in time. This was significantly higher (98.3 per cent) in medium/large enterprises compared to smaller (63.6 per cent) ones. However, in DME (28.6 per cent) workers received salaries in time. Workers were paid salaries in cash particularly in small enterprises and DMEs. When inquired about the quarterly hike in detail, they explained that migrant women largely worked for a short duration that also reflected in the salary increment period. Around 58 per cent of the workers received performance based salary hike, whereas 41 per cent reported annual increment of fixed amount. The annual hike amount varies from Rs. 100 to Rs. 500.

Safety of women workers is an important aspect at workplace. The Sexual Harassment of Women at Workplace (Prevention, Prohibition and Redressal) Act, 2013 is an important legislation which is available for protecting the working women. The definition of sexual harassment includes "Any unwelcome sexually determined behaviour such as physical contact and advances, demand or request for sexual favours, sexually coloured remarks, showing pornography, or any other unwelcome physical verbal or non-verbal conduct of sexual nature", (Krishnan et.al, 2013). Nearly 12 per cent of women workers from small enterprises and 10 per cent from medium/large enterprises reported about the some kind of sexual harassment at the workplace. Though women workers were reluctant to talk about sexual harassment in physical terms but they reported that they 
Justice for Migrant Women Workers: An Exploration from Electronics Manufacturing Sector

were exposed to derogatory remarks at the workplace. Bad comments, teasing and special favour towards some women workers was very frequent. None of the respondent reported about any physical and sexual harassment at their workplaces but they highlighted that unfavoured behaviour, commenting, teasing were common at their workplaces. Further, this Act states that the employer should set up an 'Internal Complaints Committee' at each office or branch, of an organization employing at least 10 employees. In this regard, none of the enterprises had set up any internal complaint committee. This reflects severe violation of rights of the women workers at their workplace.

In terms of social security, mainly medium/large enterprise provided the social security benefits, which ranges from gratuity (12 per cent), maternity leaves (19 per cent), medical benefits ( 26 per cent) under Employment State Insurance (ESI) act 1948, and provident fund facility (27 per cent). According to the Act, maternity leave is covered under section 50 and compensation under section 53 of ESI Act, 1948 respectively. However, only around one-fifth (19 per cent) of them said about availability of maternity leave and one-third (33 per cent) about compensation facilities in their firms. Although, the women workers get an ESI card to avail medical facilities but they do not get paid leave for being sick. Their wages are cut if they are on leave. This comes out clearly that employers manipulate the labour laws to avoid provision of stipulated benefits to workers. They manage to retain the workers by providing them only few benefits. The provision of paid leave was available only to workers in small and medium enterprises. Despite having permanent position only a small proportion of workers were able to access social security benefits. This indicates the fallacy of permanent status of the workers in the electronics manufacturing sector. It may be argued that workers may not be able to negotiate properly with the employers for their social security and other benefits.

Table7. Status of Social Security Benefits for Respondents

\begin{tabular}{|l|l|l|l|l|}
\hline Social Security Benefits & DME & Small & Medium/Large & Total \\
\hline Provident Fund & 0.0 & 3.0 & 43.3 & 27.0 \\
\hline Medical Benefits/ESI & 0.0 & 0.0 & 43.3 & 26.0 \\
\hline$* * *$ Maternity leave & 0.0 & 3.0 & 30.0 & 19.0 \\
\hline$* * *$ Compensation & 0.0 & 6.1 & 51.7 & 33.0 \\
\hline Gratuity & 0.0 & 3.0 & 18.3 & 12.0 \\
\hline Bonus & 14.3 & 6.1 & 46.7 & 31.0 \\
\hline
\end{tabular}

*** Maternity leave is covered Section 50 and Compensation is covered under Section 53 of Employee's State Insurance Act, 1948 respectively.

Source. Field Survey, 2014-15.

The ILO emphasizes that the concept of collective bargaining which consists of setting out standards of employment regulation and relations between the two parties or agreement between employers and workers (Collective Bargaining and Trade unions, n.d.). It is necessary that there should be strong, independent, democratic and well organized trade unions. But, only 1 per cent of the respondents pointed towards any presence of trade unions in their firms. None of these workers were members of any of the trade union. They even denied their association and participation with the any trade unions as the presence of work in the office and at home makes it difficult for these women to spend time on collective bargaining. These women also felt that the trade unions don't work to solve the problems of women workers. Gangoli (2007) also elaborated that women worker issues are often seen as less important than general issues. She further illustrates that trade unions believe that being a minority, women's issues divides the working class and they do not address 
the issues of inequality against women that lead to discrimination against them at the workplaces including differential in salary or wages and even to health and safety issues.

\section{CONCLUSION}

This research is a new attempt from an inter-disciplinary perspective to examine the women workers' rights at the workplace in electronics industry. There is a dearth of studies related to migrant women for this modern sector, which constituted a large portion of their workforce. The study provides some important insights, which can help in improving the employment conditions of women in the overall manufacturing industries and contribute to the future policy making.

Women workers in the industry should be provided specialised and advanced training to make their upward mobility possible. Low-skilled women are unable to access better jobs in the industry and education level emerges as an important condition for accessing decent jobs. Formal and high skilled jobs are considered decent jobs in term of remuneration and other facilities. So, higher level of skill training is necessary for the improvement of women's working condition in the job market or access to justice.

There is a fallacy in defining the category of permanent workers. The expansion of contractual jobs in formal or industrial sector shows an opposite trend as discussed historically in dual sector theory of Lewis. The concept of flexibility (contract jobs with more hours of work) has led to deterioration of formal jobs and increase in proportion of informal jobs within the formal sector. These new, formal or permanent jobs in the industry are almost similar as informal jobs with less social security benefits, low salaried and are contractual type. This is a serious problem that most of the women workers in the industry were either without any job contract or short term contact only with job breaks in between, which employers practiced to avoid legal obligations and social security benefits. Hence the government should act towards providing universal social security benefits to all workers, which can be a good step in the direction of access to justice or decent work.

For the workers to access justice, they must understand their rights and the means to claim them. Therefore, spreading awareness and proper coordination among the stakeholders (workers, employers and state) is a must. There is a lack of knowledge or information among workers and entrepreneurs regarding various Acts. The awareness of these acts among stakeholders is necessary and coordination for proper implementation of the same is essential too. This can be done by the use of information and communication technology tools like social media and facilitating centre. So, overall working environment in the industry, such as health conditions, communication between employers and workers, social security and wages or salaries and others workplace facilities can be improved to achieve access to justice or decent working conditions.

There is need to modify old Interstate Migrant Act, 1979. This Act was made when the industrial setting was totally different. The technical advancement and globalization has made lots of changes in labour hiring and recruitment practices over the years. Accordingly, this acts needs modification as per the present scenario. Access to justice needs to be strengthened by developing strategies that address issues to accessing justice in the industrial domain.

Future research in this field can be extended to All India and South Asia level either in the electronics sector or other manufacturing sectors to understand the holistic scenario of access to justice in the industrial setting.

\section{REFERENCES}

Alam, D. (2009). Women in Labour Market: An Aspect of Social Justice in R. Ahmad (Eds.). Micro- Finance and Women Empowerment (Vol.-3); New Delhi: Mittal Publications; pp.: 719-726.

Bacchus, N. (2005). The Effects of Globalization on Women in Developing Nations; paper accessed on 12 March, 2013 from http://digitalcommons.pace. edu/honorscollege theses/2

Banerjee, N. (1988). Small and Large Units: Symbiosis or Matsyanyaya in K.B. Suri (Eds.). Small Scale Enterprises in Industrial Development: The Indian Experience; New Delhi: Sage; pp.: 184-202.

American Research Journal of Humanities and Social Sciences

Page 16 
Justice for Migrant Women Workers: An Exploration from Electronics Manufacturing Sector

Barry, A.M. \& Brunt, B.M. (2002). Female Employment in the Multinational Electronics Industry in Ireland's South-West Planning Region; Irish Geography, 35(1), pp.: 28-39.

Bormann, S; Krishnan, P., Neuner, M. (2010).Migrant Workers in the Malaysian Electronics Industry: Case Studies on Jabil Circuit and Flextronics; Berlin: Weed.

Chaudhari, B. \&Panigrahi, A. K. (2013). Gender Bias in Indian Industry; The Journal of Industrial Statistics; 2(1); pp.: 108-127.

Chhachhi, A. (1997). Dormant Volcanoes or Fresh Green Vegetables: Women Electronic Workers in Delhi. Institute of Social Studies and FREA accessed on December, 3; 2012 from https://cryptome.org/2014/03/ in-electronics-industry-1997.pdf

Chhachhi, A. (1999). Gender, Flexibility, Skill and Industrial Restructuring: The Electronics Industry in India (Working Paper: 296); Hague: Institute of Social Studies retrieved from http://repub.eur.nl/res/pub/19041/ wp296.pdf

Chhachhi, A. and Pittin, R. (eds.) (1996), Confronting State, Capital and Patriarchy: Women Organising in the Process of Industrialisation; London: Macmillan.

Deshingkar, P. and Start.D (2003).Seasonal Migration for Livelihoods in India: Coping, Accumulation and Exclusion Working Paper No. 220; London: Overseas Development Institute).

Elson, D. and Pearson, R. (Spring, 1981). Nimble Fingers Make Cheap Workers: An Analysis of Women's Employment in Third World Export Manufacturing; Feminist Review; IssueNo. 7; pp.: 87-107.

Gangoli, G. (2007). Law, Patriarchies and Violence in India; England: Ashgate Publishing Ltd.

India Labour and Employment Report (2014). India Labour and Employment Report: Workers in the Era of Globalisation; Academic Foundation and Institute of Human Development: New Delhi

International Labour Organisation (2013).India: Why is Women's Labour Force Participation Dropping? Accessed on July, 18; 2013 from http://www.ilo.org/global/about-the-ilo/newsroom/comment-analysis/ WCMS_204762/lang--en/index.htm

International Labour Organisation (n.d.).ILO Estimates Over 1 Million Work-Related Fatalities Each Year; retrieved on 18 January, 2015from http://www.ilo.org/global/about-the-ilo/media-centre/press-releases/ WCMS_007969/lang--en/index.htm

International Labour Organisation (n.d.).Decent Work Agenda; retrieved from http://www.ilo.org/global/ about-the-ilo/decent-work-agenda/lang--de/index.htm

International Labour Organisation (n.d.).ILO Estimates Over 1 Million Work-Related Fatalities Each Year; retrieved on 18 January, 2015 from http://www.ilo.org/global/about-the-ilo/media-centre/press-releases/ WCMS_007969/lang--en/index.htm

Jhabavala, R. and Sinha, S. (2002). Liberalisation and the Women Workers, Economic and Political Weekly; 37(21); pp.:2037-44.

Kanan, K P and Raveendran, G. (2012). Counting and Profiling the Missing Labour Force; Economic and Political Weekly, 46(6); pp.:43-59.

Kaur, A. (2004), Economic Globalisation, Trade Liberalisation and Labour-Intensive Export Manufactures: An Asian Perspective in AmarjitKaur (Eds.) Women workers in Industrialising Asia: Costed, Not Valued; New York: Palgrave; pp: 37-58.

Lal, J.(2011). (Un) Becoming Women: Indian Factory Women's Counter Narratives of Gender, The Sociological Review, 59(3); pp.: 553-578. 
Justice for Migrant Women Workers: An Exploration from Electronics Manufacturing Sector

Lerche, J. (2012). Labour Regulations and Labour Standards in India: Decent Work; Global Labour Journal; 3(1); pp.: 16-39.

Lewis, W.A. (1954), Economic Development and Unlimited Supplies of Labour, Manchester School of Economic and Social Science, 22(2), pp. 139-191.

Lu, J. L. (2011). Occupational Health and Safety of Women Workers: Viewed in the Light of Labor Regulations; Journal of International Women's Studies, 12(1), pp.: 68-78.

Mazumdar, I. (2007). Women Workers and Globalisation: Emerging Contradictions in India. Kolkata: Stree publication.

Mehrotra, S., Gandhi, A, Sahoo, BK and Saha, P. (2012).Creating Employment in the Twelfth Five-Year Plan; Economic \& Political Weekly, XLVII (19); pp.: 63-73.

Mehta, B.S. (2012). Employment in the Information and Communication Technology Sector; The Indian Journal of Labour Economics; 55(4); pp.: 687-696.

Mehta, B.S. and Sarkar, S. (September, 2010). Income Inequalities in India: Pre and Post Reforms Period, Economic \& Political Weekly, 45(37); pp.: 45-55.

National Sample Survey (2007-08).Employment, Unemployment and Migration (64 ${ }^{\text {th }}$ Round).Unit level Data; NSSO, Government of India

Papola, T.S. (2012). Employment in Post Reform Period presented in $54^{\text {th }}$ Annual Conference of The Indian social of labour economics held in Varanasi on, 20-22 December, 2012.

Ramanamma, A. \&Bambawale, U. (1987). Women in Indian industry; Delhi, India: Mittal Publications.

Rustagi, P. (2013). Changing patterns of labour Force participation and Employment of Women in India; Indian Journal of Labour Economics; 56(2), pp.: 217-241.

Shree, M. (September, 2015). Women Employment in Indian Electronics Manufacturing Sector; Asian Journal of Research in Social Sciences and Humanities; 5(9), pp. 69-78.

South Asia Human Rights Documentation Centre (SAHRDC, 2012). Introducing Human Rights: An Overview Issues of Gender Justice, Environmental and Consumer Law.New Delhi: Oxford University Press.

Srivastava, R. (2011). Internal Migration in India: An Overview of its Features, Trends and Policy Challenges in National Workshop on Internal Migration and Human Development in India Workshop Compendium Vol. II: Workshop Papers; United Nations Educational, Scientific and Cultural Organization\&United Nation's International Children's Emergency Fund; retrieved on December, 17; 2012 from http://www.unesco.org/ new/fileadmin/MULTIMEDIA/FIELD/New_Delhi/pdf/Internal_Migration_Workshop_-_Vol_2_07.pdf

Standing, G. (1989). Global Feminisation through Flexible Labour; World Development; 17 (7); pp.:1077-95.

Theobald, S. (2002). Gendered Bodies: Recruitment, Management and Occupational Health in Northern Thailand's Electronics Factories Northern Thailand's Electronics Factories; Women \& Health; 35(4); pp. 7-26.

Citation: Megha Shree "Justice for Migrant Women Workers: An Exploration from Electronics Manufacturing Sector". American Research Journal of Humanities and Social Sciences; V3, I1; pp:1-18.

Copyright (C) 2017 Megha Shree This is an open access article distributed under the Creative Commons Attribution License, which permits unrestricted use, distribution, and reproduction in any medium, provided the original work is properly cited. 